\title{
Pengaruh Tenure, Rotasi dan Spesialisasi Kantor Akuntan Publik (KAP) Terhadap Kualitas Audit: Perbandingan Sebelum dan Sesudah Regulasi Rotasi KAP di Indonesia
}

\author{
Fitriany ${ }^{1 *}$, Sidharta Utama ${ }^{1}$, Dwi Martani ${ }^{1}$, Hilda Rosietta ${ }^{1}$ \\ Fakultas Ekonomi dan Bisnis, Universitas Indonesia \\ Jl. Dr. Sumitro Djojohadikusumo (Lkr. Kampus Raya)), Depok \\ * Penulis korespondensi; email: fitri_any@yahoo.com
}

\begin{abstract}
ABSTRAK
Indonesia merupakan negara yang menerapkan peraturan rotasi audit (akuntan publik) yang bertujuan untuk meningkatkan kualitas audit. Penelitian ini bertujuan untuk menguji pengaruh rotasi audit dan lamanya mengaudit terhadap kualitas audit. Kualitas audit diukur dengan empat kualitas laba (predictive value, timeliness, representational faithfulness dan netralitas). Sampel penelitian adalah perusahaan-perusahaan yang terdaftar di Bursa Efek Indonesia selama periode sebelum regulasi rotasi audit diberlakukan yaitu tahun 1999-2001 dan periode paska regulasi yaitu tahun 2004-2008. Hasil pengujian membuktikan bahwa pada periode sebelum regulasi, tidak ada pengaruh lamanya mengaudit terhadap kualitas audit. Namun setelah periode regulasi, lamanya mengaudit memiliki hubungan convex dengan kualitas audit dari sudut pandang netral sampai dengan timeliness. Penelitian ini juga menemukan bahwa secara umum tidak ada pengaruh rotasi akuntan publik dengan kualitas audit, 2 dari 8 persamaan regresi menunjukkan rotasi audit menurunkan kualitas audit pada periode sebelum dan sesudah regulasi. Spesialisasi memiliki pengaruh positif terhadap kualitas audit. Kewajiban untuk melakukan rotasi audit tidak cukup efektif untuk meningkatkan kualitas audit.
\end{abstract}

Kata kunci: Audit Quality, Audit Rotation, Audit Tenure, Specialization, Quadratic model.

\begin{abstract}
Indonesia is a country that not only applied the rule of audit partner rotation, but also audit firm rotation with aim to improve the audit quality. This research tries to investigate the impact of audit firm audit rotation and audit tenure to the audit quality. The audit quality is measured by four earning quality (predictive value, timeliness, representational faithfulness and neutrality perspective). The sample data are the public listed companies from period before the regulation (1999-2001) to period after the regulation (2004-2008). This research finds that in the pre-regulation period, generally there is no impact of audit firm tenure to audit quality. In the after regulation period, audit firm tenure has convex relationship with audit quality from neutrality and timeliness perspectives with minimum point at 10 and 8.3 years (decrease for 10 years and 8.3 years and then increase). As the decrease period is quite long, we can conclude that the relationship between audit firm tenure and audit quality is negative. This research also found that generally no impact of audit rotation on audit quality, but 2 from 8 regression found that audit rotation decrease the audit quality in the pre and after regulation period. Specializations have positive impact to audit quality. Mandatory audit firm rotation may not be the most efficient way to enhance audit quality.
\end{abstract}

Keywords: Audit Quality, Audit Rotation, Audit Tenure, Specialization, Quadratic model.

\section{PENDAHULUAN}

Berbagai skandal laporan keuangan menimbulkan rendahnya persepsi publik terhadap kualitas audit. Untuk itu pemerintah berusaha membuat berbagai aturan untuk mengatasi masalah tersebut, salah satunya adalah mengenai keharusan melakukan pergantian (rotasi) akuntan publik
(AP) atau kantor akuntan publik (KAP). Publikasi pada website Earnest and Young pada maret 2013 menyebutkan bahwa Uni Eropa, India dan Amerika Serikat saat ini sedang mempertimbangkan untuk mewajibkan rotasi KAP, Brazil, Cina, Belanda dan Turki baru-baru ini memperbaiki aturan mandatory rotation. Sedangkan Kanada, Republik Ceko, Korea, Latvia, Singapura dan 
Republik Slowakia awalnya mengadopsi rotasi wajib bagi KAP tapi kemudian menghapusnya.

Aturan rotasi AP dan KAP diberlakukan di Indonesia sejak tahun 2002 yang membatasi masa perikatan suatu KAP dengan kliennya maksimal lima tahun berturut-turut dan AP maksimal tiga tahun berturut-turut. Aturan ini direvisi pada tahun 2008 di mana pembatasan masa pemberian jasa KAP diubah menjadi maksimal enam tahun berturut-turut.

Rotasi KAP di Indonesia menarik untuk diteliti karena di Indonesia, perusahaan tidak hanya berkewajiban melakukan rotasi akuntan publik, tetapi juga rotasi kantor akuntan publik. Aturan rotasi di Indonesia memungkinkan suatu KAP melakukan perubahan nama dengan mengubah komposisi Akuntan Publik sehingga jumlah Akuntan Publiknya melebihi 50\% dari Akuntan Publik yang telah menjadi partner sebelumnya, maka KAP tersebut dapat dianggap sebagai KAP baru sehingga seluruh kliennya dianggap sebagai klien baru dan KAP tersebut dapat terus memberikan jasa audit kepada perusahaan tersebut. Dengan aturan ini, banyak KAP melakukan perubahan komposisi partner audit untuk menyiasati keharusan melakukan rotasi. Hasil penelitian Siregar et al. (2009) menunjukkan bahwa sebagian besar rotasi yang terjadi setelah tahun 2003 adalah rotasi semu. Yang dimaksud dengan rotasi semu pada penelitian ini adalah perubahan nama KAP dengan cara mengubah komposisi partner audit sehingga seolah-olah telah terjadi rotasi, padahal KAP-nya tidak berubah. Sedangkan yang dimaksud dengan rotasi riil adalah jika benarbenar terjadi pergantian KAP yang mengaudit suatu perusahaan, bukan hanya perubahan komposisi partner atau perubahan nama KAP.

Tabel 1 berikut menyajikan data mengenai rotasi auditor pada periode sebelum dan setelah dikeluarkannya aturan rotasi auditor berdasarkan observasi terhadap 1.846 firm year sejak tahun 1999 sampai 2007. Dari tabel tersebut terlihat bahwa terjadi peningkatan rotasi AP dan rotasi KAP yang sangat signifikan setelah dikeluarkannya aturan rotasi.

Tabel 1. Rotasi Auditor Periode 1999-2007 di Indonesia

\begin{tabular}{ccrrr}
\hline \multirow{2}{*}{ Tahun } & \multirow{2}{*}{ Rotasi AP } & $\begin{array}{c}\text { Rotasi } \\
\text { KAP }\end{array}$ & RAtasi Riil & Rotasi KAP \\
& & Semu \\
\hline 1999 & 0 & 11 & 11 & \\
2000 & 2 & 9 & 9 & \\
2001 & 0 & 14 & 14 & \\
2002 & Mulai aturan rotasi & & & \\
2003 & Mulai aturan rotasi & & & \\
2004 & 125 & 106 & 47 & 59 \\
2005 & 111 & 84 & 42 & 42 \\
2006 & 120 & 123 & 48 & 75 \\
2007 & 68 & 29 & 29 & 0 \\
\hline Total & $\mathbf{4 2 6}$ & $\mathbf{3 7 6}$ & $\mathbf{2 0 0}$ & $\mathbf{1 7 6}$ \\
\hline \multicolumn{5}{c}{}
\end{tabular}

Pengaruh rotasi audit terhadap kualitas audit masih menjadi perdebatan. Pendukung rotasi berpendapat bahwa rotasi dapat meningkatkan independensi. Hal ini sesuai dengan temuan Gavious (2007) bahwa hubungan jangka panjang antara auditor dan klien akan menimbulkan masalah independensi, sehingga perlu dibuat aturan rotasi. Penentang rotasi berpendapat bahwa kewajiban rotasi dapat menurunkan kompetensi kareena kewajiban rotasi akan menimbulkan risiko pelaksanaan audit di bawah standar karena auditor belum memahami kliennya. St. Pierre dan Anderson (1984) menemukan bahwa banyak kesalahan-kesalahan audit dan perbuatan melawan hukum auditor terjadi pada tahun-tahun awal penugasan audit.

Hubungan jangka waktu pemberian jasa audit (tenure) dengan kualitas audit juga masih menjadi perdebatan. Ada yang berpendapat bahwa semakin panjang tenure, kualitas audit semakin turun (hubungan negatif), namun juga ada yang berpendapat sebaliknya bahwa semakin panjang tenure, kualitas audit semakin meningkat (hubungan positif). Hubungan negatif antara lain didukung oleh Davis et al,(2002) yang menemukan bukti bahwa semakin panjang tenure, kualitas pelaporan keuangan semakin rendah karena hubungan auditor dan manajemen semakin dekat, sehingga manajemen memperoleh fleksibilitas yang lebih tinggi untuk membuat laporan keuangan yang sesuai dengan keinginannya. Hubungan positif didukung antara lain oleh Geiger dan Raghunandan (2002) yang menemukan bahwa banyak kegagalan audit terjadi pada tahun-tahun awal perikatan audit. Semakin panjang tenure, kualitas audit akan semakin baik. Carcello dan Nagy (2004) juga menemukan bahwa kecurangan pelaporan keuangan lebih sering terjadi pada tiga tahun awal perikatan audit. Ketika tenure semakin panjang, auditor akan semakin memahami perusahaan, kecurangan manajemen semakin berkurang, dan kualitas laporan keuangan semakin baik.

Sebagian besar penelitian mengenai hubungan tenure dengan kualitas audit menghipotesiskan hubungan yang berbentuk linier positif atau linier negatif. Dalam penelitian ini diduga bahwa hubungan tenure dan kualitas audit adalah kuadratik (concave atau conveks). Artinya, ada titik optimal dalam pemberian jasa audit. Sebelum mencapai titik optimal, tenure dapat berhubungan positif (negative) dengan kualitas audit, setelah mencapai titik optimal, tenure dapat berhubungan negatif (positif) dengan kualitas audit. Wibowo dan Rosietta (2009) menguji bentuk nonlinier ini dengan menggunakan earning surprise benchmark sebagai proksi kualitas audit, namun belum dapat 
membuktikan secara signifikan bentuk hubungan kuadratik tersebut. Fitriany dan Wibowo (2009) mengunakan kualitas laba (akrual diskresioner) sebagai proksi kualitas audit dan berhasil membuktikan bentuk hubungan kuadratik concave antara kualitas audit dan tenure. Siregar et al. (2009) menemukan hubungan kuadratik untuk kualitas audit yang diukur dengan akrual diskresioner, namun tidak untuk Earnings Response Coefficient (ERC). Davis et al. (2009) meneliti hubungan kuadratik antara tenure dan akrual diskresioner yang dilakukan oleh perusahaan dalam rangka meet atau beat earnings forecasts pada periode sebelum dan setelah SOX. Hasil penelitiannya menyimpulkan bahwa pada periode sebelum SOX, tenure dan manajemen laba berhubungan kuadratik, tapi setelah SOX, hubungan kuadratik tersebut tidak terbukti. Penelitian ini juga berusaha memberi landasan teori yang lebih kuat dari bentuk hubungan nonlinier tersebut.

Pada umumnya studi tentang pengaruh rotasi tidak membedakan antara rotasi semu dan rotasi riil. Di Indonesia, masalah ini penting karena pada rotasi semu yang berubah hanya komposisi partnernya saja sedangkan pada rotasi riil benar-benar terjadi pergantian KAP. Bentuk hubungan concave antara tenure dan kualitas audit sebenarnya telah diteliti oleh Wibowo dan Rosietta (2009), Fitriany dan Wibowo (2009), Siregar et al. (2009). Ketiga penelitian tersebut menghitung tenure KAP berdasarkan nama KAP, tidak memperhatikan apakah perubahan nama KAP tersebut hanyalah bersifat semu. Penelitian ini mengukur tenure riil, bukan tenure semu.

Variabel lain yang diteliti pada penelitian ini adalah spesialisasi auditor. Penelitian terdahulu menyimpulkan bahwa spesialisasi auditor pada industri tertentu dapat meningkatkan kemampuan auditor dalam menentukan keandalan laporan keuangan klien dan estimasi-estimasinya (Hammrsley 2006) dan menghasilkan nilai akrual diskresioner yang lebih kecil serta earnings response coefficients yang lebih besar (Krishnan 2003 dan Balsam et al. 2003).

Kualitas audit dapat diukur dari sisi input, output dan proses. Pada penelitian ini kualitas audit akan diukur output yaitu kualitas laba yang dihasilkan. Semakin baik kualitas laba yang dihasilkan dari suatu proses audit, semakin baik kualitas audit tersebut. Penelitian ini mengikuti Velury \& Jenkins (2006) yang membagi kualitas laba menjadi empat dimensi yaitu predictive value, neutrality, timeliness dan representational faithfulness.

Penelitian ini bertujuan untuk meneliti (1) Bagaimanakah pengaruh tenure KAP terhadap kualitas audit; (2) Apakah hubungan tenure KAP dan kualitas audit berbentuk kuadratik; (3) Bagaimanakah pengaruh rotasi KAP terhadap kualitas audit; (4) Bagaimanakah pengaruh spesialisasi auditor terhadap kualitas audit.

Penelitian ini diharapkan dapat memberi kontribusi untuk pengembangan model penelitian selanjutnya, agar tidak hanya terbatas pada model yang berbentuk linier saja. Diharapkan penelitian ini dapat memberi masukan bagi Departemen Keuangan dan IAPI untuk pengembangan regulasi jasa akuntan publik di Indonesia.

\section{Teori Keagenan dan Kualitas Audit}

Teori keagenan dari Jensen dan Meckling (1976) menjelaskan hubungan kontraktual antara pemilik/pemegang saham dengan agen/manajer. Dalam kontrak, agen harus bekerja sesuai delegasi wewenang dari pemilik/pemegang saham. Namun, karena ada motivasi kepentingan pribadi (self interest) yang dalam kenyataannya manajer tidak selalu bertindak sesuai keinginan pemilik. Salah satu penyebabnya adalah moral hazard (keinginan manajer bertindak untuk kepentingan pribadi). Hal ini dapat terjadi karena adanya asimetri informasi antara manajer dan pemilik. Oleh karena itu, dibutuhkan pihak ketiga yang independen sebagai mediator yaitu eksternal auditor yang akan memberikan opini atas kewajaran laporan keuangan yang dibuat manajer. Penggunaan auditor eksternal yang independen diharapkan dapat mengurangi agency cost (Jensen dan Meckling 1976; Watts dan Zimmerman 1986).

Stewardship hypothesis dalam Watt dan Zimmerman (1986) menyatakan bahwa laporan keuangan dan auditing dibutuhkan untuk memeriksa kejujuran dan reliability laporan yang dibuat manajer dan sebagai alat untuk memonitor kontrak antara manajer dan pemilik. Manajer akan berusaha untuk memilih auditor yang dapat membangun image manajer sebagai the good steward.

Di sisi lain, dalam moral hazard hypothesis manajer mempunyai kecenderungan untuk memaksimalkan tingkat kesejahteraannya dengan mengorbankan tingkat kesejahteraan pemilik. Manajer cenderung memilih auditor yang memberi keleluasaan pada manajer untuk memilih prosedur akuntansi yang disukai manajer. Namun, sekaligus juga bersedia memberi opini audit yang menguntungkannya.

Masalah keagenan auditor bersumber pada mekanisme kelembagaan. Auditor ditunjuk oleh pihak manajemen untuk melakukan audit bagi kepentingan pemegang saham, tetapi jasa audit dibayar oleh manajemen (Gavious, 2007). Hal ini menciptakan benturan kepentingan yang tidak bisa dihindari auditor. Mekanisme kelembagaan 
ini menimbulkan ketergantungan auditor kepada kliennya sehingga auditor dapat kehilangan independensinya dan harus mematuhi berbagai keinginan klien dengan harapan perikatan auditnya di masa depan tidak terputus.

Palmrose (1984) serta Healy dan Lys (1986) menyatakan bahwa kualitas audit merupakan indikator utama dalam pemilihan auditor. Artinya, kualitas pelayanan jasa auditor yang diberikan terhadap klien merupakan dasar pertimbangan utama dalam memilih auditor. Konsisten dengan teori keagenan, manajemen perusahaan senantiasa ingin memuaskan keinginan investor dengan memilih auditor yang dapat merefleksikan citra manajer yang baik di mata investor.

Di lain pihak, terdapat masalah keagenan dari sisi auditor di mana auditor memiliki kepentingan mempertahankan dan meningkatkan pendapatan jasa auditnya dengan memenuhi keinginan klien audit, terutama klien jangka panjang. Hal ini dilakukan dalam rangka menjamin kelanjutan perikatan auditnya sehingga terjamin pendapatan auditor tersebut. Insentif untuk bekerja sama dengan manajemen yang curang berasal dari ketergantungan ekonomi tersebut. Jadi, dalam kepentingan ekonomi, perikatan audit jangka panjang akan menimbulkan kedekatan dan loyalitas antara auditor dan klien. Hal ini akan menurunkan objektifitas audit dan menurunkan independensi auditor. Masalah yang perlu diperhatikan adalah jika auditor dipertahankan dalam jangka waktu lama, kemungkinan besar auditor tersebut akan merasa nyaman sehingga objektifitas audit akan terganggu (Mautz dan Sharaf 1961).

Namun demikian, auditor tetap harus mempertimbangkan risiko litigasi dan reputasi yang muncul dalam memaksimalkan profitabilitasnya (Reynolds dan Francis 2001). Kegagalan audit dapat berakibat pengenaan sanksi terhadap auditor oleh regulator yang akan merusak reputasi auditor. Regulator (pemerintah) berperan sebagai pelindung kepentingan publik dengan mengeluarkan kebijakan/regulasi agar kualitas audit tetap terjaga.

\section{Pengaruh Tenure terhadap Kualitas Audit}

Mautz dan Sharaft (1961) menyatakan bahwa dengan panjangnya hubungan antara auditor dengan kliennya akan memengaruhi independensi auditor karena objektifitas auditor akan menurun seiring dengan berjalannya waktu. Turunnya objektivitas ini akan meningkatkan kemungkinan kegagalan mendeteksi kesalahan pada laporan keuangan. Turunnya objektivitas dapat disebabkan oleh beberapa hal. Pertama, semakin lama auditor berhubungan dengan klien akan mengakibatkan auditor mulai bertindak sebagai pendukung manajemen. Sebagai konsekuensinya, auditor tidak memandang asersi yang disampaikan manajemen dengan professional skepticism yang tepat, akan tetapi akan memandang dalam perspektif pendukung manajemen. Kedua, semakin lama hubungan auditor dengan klien, auditor akan kurang sensitif dan gagal untuk menemukan data dan bukti baru yang diperlukan guna mendukung judgement auditor. Perilaku ini dapat mengakibatkan auditor gagal untuk merevisi judgement yang salah pada tahuntahun sebelumnya dan mungkin juga gagal memberikan judgement yang lebih tepat seiring dengan perubahan situasi bisnis klien. Argumen paling akhir adalah bahwa kemampuan untuk menahan klien akan menjadi insentif bagi auditor untuk tidak terlalu mempermasalahkan sengketa dengan klien dan cenderung mengakomodir keinginan klien dengan tujuan agar mendapatkan keuntungan ekonomi berupa tidak pindahnya klien ke auditor lain.

Berdasarkan berbagai penelitian sebelumnya, terdapat dua pendapat yang bertentangan mengenai hubungan antara tenure dan kualitas audit. Pendapat pertama mengatakan bahwa jangka waktu penugasan audit berhubungan negatif dengan kualitas audit dengan argumen bahwa semakin panjang jangka waktu audit, auditor semakin dekat (familiar) hubungan auditor dengan klien. Kedekatan ini dapat menyebabkan auditor dan klien punya peluang untuk mengkompromikan pilihan akuntansi dan pelaporan klien. Hal ini akan mengurangi independensi auditor, yang berarti menurunkan kualitas audit (Mautz dan Sharaft,1961; Kaplan 2004; Gavious 2007; Gietzmann dan Sen 2001; Dopuch et al. 2001; Chi et al. 2005).

Pendapat kedua mengatakan bahwa jangka waktu penugasan audit berhubungan positif dengan kualitas audit. Dengan kata lain, semakin panjang tenure, kualitas audit akan semakin meningkat. Hubungan positif antara tenure dan kualitas audit disebabkan karena: (i) banyak kesalahan-kesalahan audit dan perbuatan melawan hukum auditor terjadi pada tahun-tahun awal penugasan audit, semakin lama, kualitas audit akan semakin baik (St Pierre dan Anderson 1984)); (ii) penugasan baru akan meningkatkan start-up costs sehingga akan meningkatkan biaya audit secara keseluruhan (Davis et al. (2002); (iii) rotasi menimbulkan risiko pelaksanakan audit di bawah standar karena auditor belum memahami kliennya secara mendalam (Francis dan Simon 1987; Balvers et al. 1988; Beatty 1989; Craswell et al. 1995).

Pada umumnya penelitian tersebut menghipotesiskan hubungan tenure dan kualitas audit 
berbentuk linier positif atau linier negatif. Penelitian ini memprediksi bahwa hubungan tenure dan kualitas audit adalah berbentuk kuadratik dan kualitas audit akan meningkat dengan semakin lama jangka waktu penugasan audit sampai titik optimal tertentu, yang kemudian dengan bertambahnya jangka waktu audit, kualitas audit akan turun karena independensi auditor menjadi berkurang.

Ada beberapa peneliti telah mencoba bentuk hubungan nonlinier tersebut seperti Davis et al. (2009). Namun, Davis et al. (2009) hanya menggunakan satu proksi kualitas audit (akrual diskresioner). Wibowo dan Rosietta (2009) mencoba bentuk nonlinier dengan earning surprise benchmark sebagai proksi kualitas audit, namun belum dapat membuktikan secara signifikan bentuk hubungan kuadratik tersebut. Fitriany dan Wibowo (2009) serta Siregar et al. (2009) menemukan hubungan nonlinier dengan proksi akrual diskresioner saja. Pada penelitian ini akan diuji model kuadratik dengan pengukuran kualitas audit yang lebih banyak (4 proksi kualitas laba).

Model kuadratik ini dikembangkan dari definisi kualitas audit yang disampaikan oleh De Angelo (1981a) yang menyatakan bahwa kualitas audit adalah kemampuan auditor mendeteksi kesalahan dalam laporan keuangan dan kemudian melaporkannya kepada pengguna laporan keuangan. Peluang mendeteksi kesalahan tergantung pada kompetensi auditor sedangkan keberanian melaporkannya tergantung pada independensi auditor.

Hubungan kompetensi dan tenure diprediksikan berbentuk positif. Semakin panjang tenure, auditor akan semakin memiliki kompetensi karena auditor semakin memahami internal control, sistem informasi akuntansi, dan risiko spesifik perusahaan. Fitriany dan Rossieta (2009) menemukan bahwa tenure signifikan berpengaruh negatif terhadap akrual diskresioner. Pada tahun pertama penugasan, kualitas audit masih rendah, yang mungkin disebabkan karena auditor belum terlalu memahami kondisi klien, namun dengan semakin panjang tenure (yaitu tahun ke-2 dan ke3), kualitas audit terus meningkat. Namun pada tahun ke-4, pengaruh audit tenure terhadap kualitas audit tidak signifikan.

Auditor yang belum mempunyai pemahaman klien yang mendalam cenderung akan bergantung pada estimasi dan keterangan yang diberikan oleh pihak perusahaan yang diaudit (Gul et al. 2007). Hal ini sesuai dengan SPAP (2001) yang menyatakan bahwa perolehan pengetahuan tentang bisnis yang diperlukan auditor merupakan proses berkelanjutan dan bersifat kumulatif. Karena adanya learning process, tambahan pengetahuan yang didapat pada tahun awal dapat lebih banyak atau lebih sedikit daripada tahun-tahun berikutnya. Oleh karenanya, pada penelitian ini hubungan tenure dan kompetensi dihipotesiskan positif dan dapat berbentuk cembung atau cekung, seperti tampak pada Gambar 1. Gambar 1 kiri menunjukan bahwa tambahan (delta) pengetahuan yang didapat pada tahun awal penugasan lebih sedikit daripada tahun-tahun berikutnya. Sedangkan Gambar 1 kanan menunjukan bahwa tambahan (delta) pengetahuan yang didapat pada tahuntahun awal penugasan lebih banyak daripada tahun-tahun berikutnya.

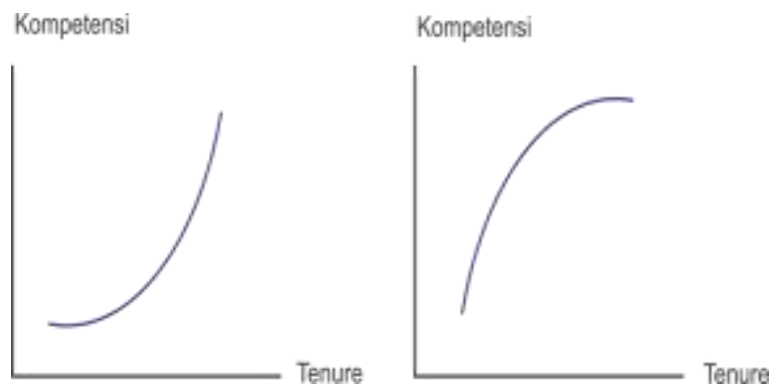

Gambar 1. Hubungan Tenure dan Kompetensi

Hubungan tenure dan independensi dihipotesiskan berbentuk negatif karena secara umum semakin panjang tenure, semakin familiar (dekat) hubungan auditor dan klien, sehingga auditor menjadi semakin tidak kritis/tidak independen. Hal ini dapat dijelaskan dengan teori Low-Balling (De Angelo 1981a). Untuk mendapatkan dan mempertahankan klien baru, auditor mengenakan biaya audit yang lebih rendah pada tahun-tahun awal masa pemberian jasa audit. Biaya audit ini akan meningkat seiring dengan bertambahnya masa perikatan. Maka auditor dengan tenure yang rendah akan lebih tolerir untuk menjaga hubungan dengan klien agar kerja sama mereka dapat berjalan panjang dan kerugian auditor pada tahun-tahun awal dapat tertutupi. Hal ini akan berdampak pada rendahnya kualitas audit dan kualitas laba (Gul et al. 2007). Berbagai penelitian lainnya juga telah menemukan bahwa semakin panjang tenure, independensi semakin turun (Gavious 2007; Gietzmann dan Sen 2001; Dopuch et al. 2001; Chi et al. 2005). Penurunan independensi ini berbeda-beda pada setiap kasus. Pada tahun-tahun awal penugasan audit, penurunan independensi dapat lebih cepat atau lebih lambat. Hal ini dapat digambarkan pada gambar 2 kiri yang menunjukkan penurunan independensi yang lebih lambat pada tahun-tahun awal penugasan sedangkan gambar 2 kanan menunjukan penurunan independensi yang lebih cepat pada tahun awal penugasan (tenure). 

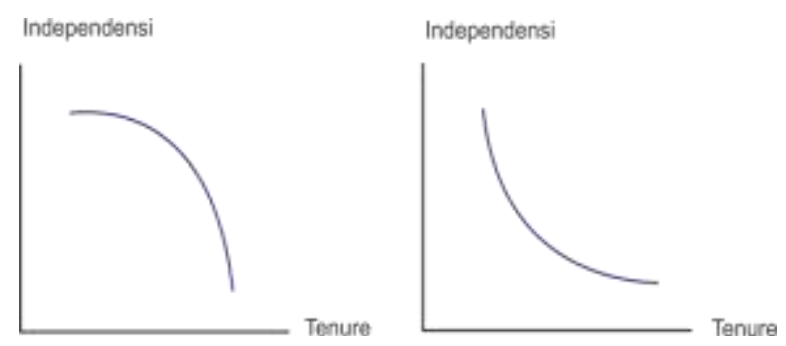

Gambar 2. Hubungan Tenure dan Independensi

Kualitas audit adalah kombinasi dari kompetensi dan independensi auditor (De Angelo, 1981a). Jika gambar 1 dan 2 digabung, dapat menghasilkan beberapa pilihan kurva seperti tampak pada gambar 3. Gambar 3.a menunjukkan bahwa pada awal masa penugasan (tenure) sampai titik optimal, peningkatan kompetensi lebih tinggi dari pada penurunan independensi sehingga kompetensi lebih dominan memengaruhi kualitas audit dibandingkan independensi. Kurva kualitas audit akan naik. Setelah titik optimal, dengan semakin panjangnya hubungan auditor dengan klien, mengakibatkan auditor dan klien semakin familiar, sehingga masalah independensi lebih dominan memengaruhi kualitas audit dibandingkan kompetensi, maka kurva kualitas audit akan turun, hubungan tenure dan kualitas audit berbentuk concave seperti tampak pada gambar 3.a.

Hubungan tenure dan kualitas audit juga dapat berbentuk conveks seperti gambar 3.b tergantung mana yang lebih dominan antara independensi dan kompetensi, selain itu juga tergantung pada bentuk kurva independensi dan kompetensi, apakah cembung atau cekung.
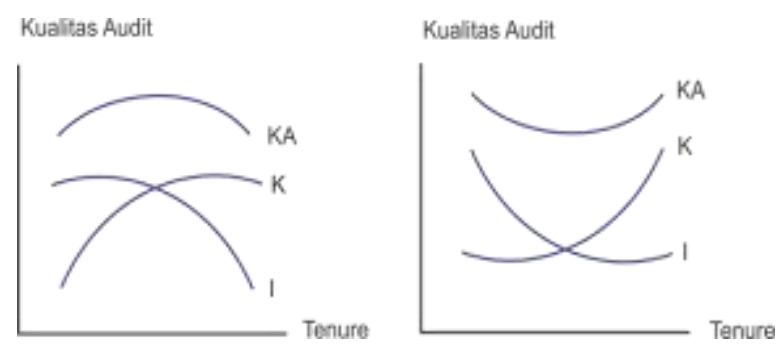

Gambar 3. Hubungan tenure dan kualitas audit

Ket: I: Independensi, K: Kompetensi, KA: Kualitas Audit

Berdasarkan penjelasan di atas, dapat dihipotesiskan bahwa hubungan kualitas audit dan tenure KAP berbentuk kuadratik (concave atau conveks), tergantung pada periode tersebut, mana yang lebih dominan, kompetensi atau independensi, sehingga hipotesis penelitian adalah sebagai berikut:

H1: Tenure KAP berpengaruh secara kuadratik terhadap kualitas audit.

\section{Pengaruh Rotasi terhadap Kualitas Audit}

Terdapat argumen yang menentang dan mendukung aturan rotasi. Penelitian yang menentang aturan rotasi diantaranya adalah St Pierre dan Anderson (1984) yang menyatakan bahwa banyak kesalahan-kesalahan audit dan perbuatan melawan hukum auditor terjadi pada tahun-tahun awal penugasan audit dan Davis et al. (2002) yang menyatakan bahwa meningkatnya frekuensi pergantian auditor akan meningkatkan biaya audit secara keseluruhan. Namun ada juga pihak yang pro (setuju) dengan penerapan aturan rotasi seperti Gietzmann dan Sen (2001) yang menemukan bahwa walaupun aturan kewajiban rotasi KAP memiliki biaya tinggi, namun aturan tersebut meningkatkan independensi auditor melebihi biaya di pasar secara relatif pada beberapa klien besar.

Berdasarkan berbagai penjelasan dan literatur di atas di mana terdapat argumen yang menyatakan bahwa rotasi audit dapat berpengaruh positif dan dapat pula berpengaruh negatif, maka hipotesis sehubungan pengaruh rotasi audit terhadap kualitas audit bersifat dua arah (twotails). Penelitian ini akan menguji rotasi rotasi KAP (Kantor Akuntan Publik), sehingga hipotesisnya adalah:

H2: Rotasi KAP berpengaruh terhadap kualitas audit.

\section{Pengaruh Spesialisasi Auditor terhadap Kualitas Audit}

Auditor spesialis artinya auditor tersebut memiliki pengalaman yang banyak dalam mengaudit klien dalam industri yang sama. Pengalaman ini berdampak pada meningkatnya pemahaman auditior tentang risiko audit spesifik pada industri tersebut. Spesialisasi ini dapat meningkatkan efisiensi dan efektivitas dalam penentuan kehandalan laporan keuangan klien dan estimasiestimasinya sehingga auditor akan mempunyai kemampuan mendeteksi kesalahan atau ketidaknormalan pada industri yang diauditnya, sehingga biasanya lebih sedikit melakukan kesalahan dibandingkan dengan auditor yang bukan spesialis (Solomon et al. 1999).

Auditor spesialis akan selalu berusaha melindungi reputasinya dengan meningkatkan ketaatan terhadap standar audit relatif terhadap non spesialis (Carcello dan Nagy 2004). Auditor yang spesialis dalam industri tertentu akan lebih percaya diri dalam menentukan inherent risk, memiliki kemampuan yang lebih tinggi dalam mendeteksi error dan financial fraud. Oleh karena itu perusahaan yang diaudit oleh auditor yang 
spesialis akan menghasilkan kualitas laba yang lebih baik karena nilai akrual diskrisioner yang lebih rendah dan earnings response coefficients yang lebih besar (Balsam 2003).

Dengan demikian peneliti memprediksi bahwa terdapat hubungan positif antara spesialisasi auditor dengan kualitas audit. Sehingga hipotesis yang diajukan adalah:

H3: Spesialisasi auditor berpengaruh positif terhadap kualitas audit.

\section{METODE PENELITIAN}

\section{Model Penelitian}

$$
\begin{aligned}
\mathrm{KA}_{\mathrm{it}}= & \mathrm{a}_{0}+\mathrm{a}_{1} \text { TENURE }_{\mathrm{it}}+\mathrm{a}_{2} \text { TENURESQ }_{\mathrm{it}}+ \\
& { }_{3} \text { ROTATION }_{\mathrm{it}}+\mathrm{a}_{4} \text { SPEC }_{\mathrm{it}}+\text { V_CONTROL }_{-} \\
& +\varepsilon_{\mathrm{it}}
\end{aligned}
$$

$\mathrm{KA}_{\mathrm{it}}$ : Kualitas Audit; TENURE: jangka waktu penugasan KAP (tahun); TENURESQ: TENURE dikuadratkan; ROTATION: dummy variable, 1 jika terjadi rotasi audit, 0 lainnya; SPEC: dummy variable, 1 jika perusahaan diaudit oleh auditor spesiali, 0 lainnya.

\section{Operasionalisasi Variabel}

\section{Kualitas Audit}

Kualitas audit memiliki banyak dimensi, dapat dilihat dari output, proses audit, input. Pada penelitian ini kualitas audit akan diukur berdasarkan output yaitu dari kualitas laba yang dihasilkan. Semakin baik kualitas laba yang dihasilkan dari suatu proses audit, semakin baik kualitas audit tersebut. Penelitian ini mengikuti Velury \& Jenkins (2006) yang membagi kualitas laba menjadi empat dimensi yaitu predictive value, timeliness, neutrality, dan representational faithfulness. Laba dikatakan berkualitas jika memiliki nilai reliability (neutrality dan representational faithfulness) dan relevansi (predictive value dan timeliness).

\section{Neutrality}

Informasi laba yang netral artinya laba harus memberi informasi yang tidak bias. Laba dikatakan netral jika laba tidak dikelola untuk tujuan tertentu (tidak ada manajemen laba). Untuk mengukur manajemen laba sebagian besar penelitian menggunakan ukuran akrual diskresioner karena prinsip akuntansi yang berlaku umum memberikan fleksibilitas bagi manajemen dalam melakukan akrual (Subramanyam, 1996). Penelitian ini menggunakan model Kasnik (1999) untuk meng- ukur nilai akrual diskresioner karena berdasarkan penelitian Siregar (2005) dan Siregar et al. (2009), model Kasnik memberi hasil yang lebih baik dibandingkan model lainnya. Dalam penelitian ini digunakan nilai absolut dari akrual diskresioner (ABS_DAC) karena yang dilihat adalah besarnya manajemen laba, bukan arahnya (Siregar, 2005). Hubungan akrual diskresioner dengan kualitas audit adalah berbanding terbalik dimana semakin tinggi tingkat akrual diskresioner, semakin besar manajemen laba, yang berarti semakin buruk kualitas laba. Kualitas laba yang buruk menunjukkan kualias audit yang juga buruk. Model penelitian menjadi:

$$
\begin{array}{r}
\text { ABS_DAC }_{\mathrm{it}}=\mathrm{a}_{0}+\mathrm{a}_{1} \text { TENURE }_{\mathrm{it}}+\mathrm{a}_{2} \text { TENURESQ }_{\mathrm{it}} \\
+\mathrm{a}_{3} \text { ROTATION }_{\mathrm{it}}+\mathrm{a}_{4} \mathrm{SPEC}_{\mathrm{it}}+\mathrm{a}_{5} \mathrm{BIG}_{\mathrm{it}}+ \\
\mathrm{a}_{6} \mathrm{LEV}_{\mathrm{it}}+\mathrm{a}_{7} \mathrm{GROWTH}_{\mathrm{it}}+\mathrm{a}_{8} \mathrm{SIZE}_{\mathrm{it}}+ \\
\mathrm{a}_{9} \mathrm{D}_{2} \mathrm{LOSS}_{\mathrm{it}}+\mathrm{a}_{10} \mathrm{CFO}_{\mathrm{it}}+\varepsilon_{\mathrm{it}}
\end{array}
$$

dimana:

ABS_DACit: absolut discretionary accruals; TENURE: jangka waktu penugasan KAP (tahun); TENURESQ: TENURE dikuadratkan; ROTATION: dummy variable, 1 jika terjadi rotasi audit, 0 lainnya; SPEC: dummy variable, 1 jika equal perusahaan diaudit oleh auditor spesialis (memiliki market share lebih dari $10 \%$ di industri berdasarkan total asset klien) and 0 lainnya; BIG4: dummy variable, 1 jika perusahaan diaudit oleh Big4, 0 lainnya; LEV: tingkat leverage (debt-tototal asset); GROWTH: pertumbuhan perusahan (price-to-book value); SIZE: ukuran perusahaan (natural log total assets); D_LOSS: 1: jika perusahaan mengalami kerusian; CFO: Cash Flow.

Hubungan kuadratik concave (conveks) terbukti jika koefisien a1 signifikan positif (negatif) dan koefisien a2 signifikan negatif (positif).

\section{Representational Faithfulness}

Representational faithfullness dapat diartikan sebagai keharusan laporan keuangan untuk menyajikan secara jujur transaksi dan peristiwa lainnya yang seharusnya disajikan. Dimensi ini menunjukkan bahwa nilai laba yang dilaporkan merupakan hasil penyesuaian antara ukuran (measure) atau deskripsi dengan fenomena yang direpresentasikannya. Karena laba disajikan untuk menangkap nilai ekonomis suatu perusahaan, maka representational faithfullness dari angka laba dapat dilihat dengan menguji hubungan antara laba dengan return saham atau disebut sebagai earnings response coefficient (Velury dan Jenkins 2006). Untuk menghitung ERC adalah 
$\mathrm{CAR}_{\mathrm{it}}=\mathrm{a}_{0}+\mathrm{a}_{1} \mathrm{UE}_{\mathrm{it}}$ koefisien alpha (a) merupakan

ERC dari tiap perusahaan, sehingga model penelitian menjadi:

$\mathrm{CAR}_{\mathrm{i}, \mathrm{t}}=\mathrm{a}_{0}+\mathrm{a}_{1} \mathrm{UE}_{\mathrm{it}}+\mathrm{a}_{2} \mathrm{UE}_{\mathrm{it}}$ TENURE $_{\mathrm{it}}+$ $\mathrm{a}_{3} \mathrm{UE}_{\mathrm{it}}{ }^{*}$ TENURESQ $_{\mathrm{it}}+\mathrm{a}_{4} \mathrm{UE}_{\mathrm{t}} *$ ROTATION $_{\mathrm{it}}+$ $\mathrm{a}_{5} \mathrm{SPEC}_{\mathrm{it}}+\mathrm{a}_{6} \mathrm{BIG}_{\mathrm{it}}+\mathrm{a}_{7} \mathrm{LEV}_{\mathrm{it}}+\mathrm{a}_{8} \mathrm{GROWTH}_{\mathrm{it}}+$ $\mathrm{agSIZE}_{\text {it }}+\mathrm{a}_{10} \mathrm{D}_{-} \mathrm{LOSS}_{\mathrm{it}}+\mathrm{a}_{11} \mathrm{STDEV}_{\mathrm{it}}+\varepsilon_{\mathrm{it}}$

dimana:

$\mathrm{CAR}_{\mathrm{it}}$ : Cumulative Abnormal Return (weekly);

$\mathrm{UE}_{\mathrm{it}}$ : Unexpected Earning

\section{Predictive value}

Prediktabilitas laba adalah kualitas informasi yang membantu pengguna laporan keuangan memprediksi hasil dimasa depan dengan berdasarkan dari kejadian masa lalu dan sekarang dengan lebih baik. Untuk menguji apakah laba memiliki predictive value, dapat dilihat pada hubungan antara current earnings dan operating cash flow di masa mendatang (Velury Jenkins, 2006). Semakin besar hubungan antara laba tahun berjalan dengan arus kas masa mendatang, semakin besar tingkat prediktabilitas laba. Velury dan Jenkins (2006) merumuskan cara untuk menghitung predictive value sebagai berikut $\mathrm{CFO}_{\mathrm{i}, \mathrm{t}}=\mathrm{a}_{0}+\mathrm{a}_{1} \mathrm{INC}_{\mathrm{it}}+\mathrm{e}$ sehingga model penelitian menjadi:

$\mathrm{CFO}_{\mathrm{i}, \mathrm{t+1}}=\mathrm{a}_{0}+\mathrm{a}_{1} \mathrm{INC}_{\mathrm{it}}+\mathrm{a}_{2} \mathrm{INC}_{\mathrm{it}}{ }^{*} \mathrm{TENURE}_{\mathrm{it}}+$ $\mathrm{a}_{3} \mathrm{INC}_{\mathrm{it}}{ }^{*} \mathrm{TENURESQ}_{\mathrm{it}}+\mathrm{a}_{4} \mathrm{INC}_{\mathrm{it}}{ }^{*}$ ROTATION $_{\mathrm{it}}$ $+\mathrm{a}_{5} \mathrm{SPEC}_{\mathrm{it}}+\mathrm{a}_{6} \mathrm{BIG}_{\mathrm{it}}+\mathrm{a}_{7} \mathrm{LEV}_{\mathrm{it}}+\mathrm{a}_{8} \mathrm{GROWTH}_{\mathrm{it}}+$ agSIZE $_{\text {it }}+$ a $10_{0} D_{L}$LOSS $_{\mathrm{it}}+\varepsilon_{\mathrm{it}}$

dimana:

$\mathrm{CFO}_{\mathrm{i}, \mathrm{t}+1}$ : arus kas operasi (diskala dengan total aset) paa akhir tahun t+1; INC: laba sebelum pospos luar biasa dan discontinued operation diskala dengan total aset.

\section{Timeliness}

Collins et al. (1994) and Gelb and Zarowin (2002) menyatakan bahwa earnings dengan tingkat timeliness yang rendah akan menghasilkan hubungan yang rendah antara current returns dan current earnings. Lundholm and Myers (2002) menyatakan bahwa informative disclosure (transparent earnings) akan menyebabkan current returns lebih merefleksikan informasi mengenai future earnings. Penelitian ini mengikuti Raonic et al. (2004), Dimitropoulos et al. (2008) dan Ding dan Stowoly (2006) dalam menentukan timeliness of earnings. Earnings dikatakan timely ketika earnings merefleksikan informasi yang diberikan ke market dalam menilai harga saham suatu perusahaan. Model econometric untuk menentukan timeliness of earnings adalah $\mathrm{EPS}_{\mathrm{it}}=\mathrm{a}_{0}+\mathrm{a}_{1} \mathrm{R}_{\mathrm{it}}$, sehingga model menjadi:

$\operatorname{EPS}_{\mathrm{it}}=\mathrm{a}_{0}+\mathrm{a}_{1} \mathrm{R}_{\mathrm{it}}+\mathrm{a}_{2} \mathrm{R}_{\mathrm{it}}{ }^{*} \mathrm{TENURE}_{\mathrm{it}}+$

$\mathrm{a}_{4} \mathrm{R}_{\mathrm{it}}{ }^{*}$ TENURESQ $_{\mathrm{it}}+\mathrm{a}_{6} \mathrm{R}_{\mathrm{it}}{ }^{*}$ ROTATION $_{\mathrm{it}}+$ $\mathrm{a}_{7} \mathrm{SPEC}_{\mathrm{it}}+\mathrm{a}_{4} \mathrm{BIG}_{4}+\mathrm{a}_{6} \mathrm{LEV}_{\mathrm{it}}+\mathrm{a}_{9} \mathrm{GROWTH}_{\mathrm{it}}+$

$\mathrm{a}_{4} \mathrm{SIZE}_{\mathrm{it}}+\mathrm{a}_{4} \mathrm{D}_{-} \mathrm{LOSS}_{\mathrm{it}}+\varepsilon_{\mathrm{it}}$

Dimana:

EPS $_{\mathrm{it}}$ : earnings per share scaled by beginning rice; $\mathrm{R}_{\mathrm{it}}$ : return mingguan

Hubungan kuadratik concave (conveks) pada model 1 terbukti jika koefisien a1 signifikan positif (negatif) dan koefisien a signifikan negatif (positif). Sedangkan pada model 2 sd 4 hubungan kuadratik concave (conveks) terbukti jika koefisien a2 signifikan positif (negatif) dan koefisien a3 signifikan negatif (positif).

TENURE: jangka waktu penugasan KAP oleh perusahaan (dalam satuan tahun). Diukur tenure riil

ROTASI: dummy variable, 1 jika terjadi pergantian KAP riil

SPEC: Spesialisasi audit diukur dengan persentase klien go public yang diaudit oleh suatu KAP pada suatu industri tertentu dan kemudian dilakukan pembobotan (weighting) berdasarkan total aset untuk perusahaan go public dengan rumus sebagai berikut: Spesialisasi $=$ (jumlah klien $\mathrm{KAP}$ di industri tersebut/jumlah seluruh emiten di industri) $\mathrm{x}$ (rerata aset klien KAP di industri tersebut/rerata aset seluruh emiten di industri tsb). Suatu KAP dikatakan spesialis jika KAP tersebut menguasai $10 \%$ market share (Siregar et al, 2009).

\section{Variabel Kontrol}

Variabel control untuk setiap model tersebut ada perbedaan karena dependen variabelnya berbeda. Berikut adalah variabel kontrol yang digunakan:

Tabel 3. Variabel Kontrol

\begin{tabular}{lll}
\hline & Proksi Kualias Audit & Variabel control \\
\hline 1 & Predictability & SIZE_E, GROWTH, LEV, \\
& & SIZE_KAP, LOSS \\
2 & Netralitas & SIZE_E, GROWTH, LEV, \\
& & SIZE_KAP, LOSS, CFO \\
3 & Representational & SIZE_E, GROWTH, LEV, \\
& faithfulness & SIZE_KAP, LOSS, \\
& & MKT_RISK \\
4 & Timeliness & SIZE_E, GROWTH, LEV, \\
& & SIZE_KAP, LOSS \\
\hline
\end{tabular}




\section{Ukuran Perusahaan (SIZE)}

Penelitian terdahulu menemukan ukuran perusahaan secara negatif signifikan mempengaruhi besaran akrual diskresioner perusahaan (Siregar, 2005). Lyss dan Watt (1994) berpendapat bahwa semakin buruk kondisi informasi asimetri pada suatu perusahaan, semakin leluasa manajer untuk mengambil keputusan tanpa terdeteksi oleh sistem pengendalian organisasi. Selain itu penelitian-penelitian terdahulu (Lyss dan Watt, 1994, Shu, 1999) menemukan adanya hubungan positif antara ukuran perusahaan dengan risiko litigasi sehingga memotivasi perusahaan besar untuk meningkatkan transparansi dalam pelaporan keuangan yang berarti memudahkan auditor untuk mengaudit perusahaan sehingga hubungannya dengan kualitas audit positif.

Di lain pihak, Lobo dan Zhou (2006) menemukan bahwa perusahaan besar memiliki peluang yang lebih tinggi untuk meningkatkan laba secara artifisial karena kompleksitas bisnis dan operasionalnya menyulitkan pengguna laporan keuangan untuk mendeteksi manipulasi tersebut. Semakin besar perusahaan, semakin kompleks bisnis dan operasional dan semakin rumit sistem informasi sehingga kemungkinan auditor mendeteksi manipulasi laba yang dilakukan oleh manajemen berkurang, akibatnya semakin besar kemungkinan kualitas audit yang dilakukan akan kurang baik.

Berdasarkan argumen di atas, dalam penelitian ini diperkirakan bahwa ukuran perusahaan bisa berpengaruh positif maupun negatif terhadap kualitas audit. Variabel ini diukur dengan logaritma natural total aset.

\section{Pertumbuhan Perusahaan (GROWTH)}

Chen (2004) menemukan bahwa perusahaan dengan tingkat pertumbuhan yang semakin tinggi akan cenderung memiliki nilai absolut akrual yang semakin tinggi pula. Summers dan Sweeney (1998) menyatakan bahwa manajer cenderung memanipulasi laporan keuangan ketika pertumbuhan melambat untuk mempertahankan konsistensi pertumbuhan perusahaan. Salah satu ukuran yang digunakan adalah market to book ratio, yang merupakan ekspektasi pasar tentang pertumbuhan perusahaan. Salah satu cara untuk meningkatkan harga pasar saham adalah dengan melakukan manajemen laba melalui akrual diskresioner. Semakin tinggi manajemen laba, berarti kualitas laba semakin buruk. Kualitas laba adalah sebagai proksi kualitas audit yang berarti dengan semakin rendah kualitas laba, kualitas audit juga semakin rendah. Arah tanda koefisien variabel GROWTH diekspektasi positif. Diukur dengan PBV.

\section{Leverage (LEV)}

DeFond dan Jiambalvo (1994) membuktikan bahwa perusahaan dengan tingkat hutang yang tinggi memiliki insentif untuk meningkatkan laba secara artifisial untuk memenuhi debt covenant. Namun demikian di sisi lain keberadaan kreditor juga dapat menjadi alternatif monitoring melalui penyedia dana eksternal yang memiliki dorongan dan kemampuan untuk memonitor aktivitas perusahaan (Larcker dan Richardson, 2006 dalam Jiang et al., 2008). Becker et al. (1996) menemukan bahwa tingkat hutang berhubungan negatif dengan nilai absolut akrual diskresioner.

Semakin tinggi manajemen laba, berarti kualitas laba semakin buruk. Kualitas laba adalah sebagai proksi kualitas audit yang berarti dengan semakin rendah kualitas laba, kualitas audit juga semakin rendah dan sebaliknya. Maka dalam penelitian ini diperkirakan bahwa tingkat hutang bisa berpengaruh positif maupun negatif terhadap kualitas audit.

\section{Kerugian (LOSS)}

LOSS mencerminkan kondisi keuangan perusahaan. Perusahaan yang mengalami kerugian punya insentif lebih besar untuk melakukan manajemen laba dengan melakukan big bath (Kallapur et al, 2008). Manajemen laba yang semakin besar menunjukkan kualitas audit yang kurang baik. Sehingga hubungan LOSS dengan kualitas audit diprediksikan negatif.

\section{Cash Flow from Operation (CFO)}

CFO mencerminkan kondisi kas perusahaan. Perusahaan yang memiliki kondisi kas yang baik akan memiliki kualitas laba yang baik pula, begitu pula sebaliknya (Velury dan Jenkins, 2006). Lobo dan Zhou (2006), serta Becker et al., (1998) menyatakan bahwa perusahaan dengan kinerja arus kas operasional yang bagus memiliki kemungkinan yang lebih kecil untuk melakukan manipulasi laba yang tinggi secara artifisial. Sebaliknya, perusahaan dengan arus kas operasional yang buruk lebih mungkin melakukan manipulasi laba yang tinggi secara artifisial untuk mengirim signal positif bagi investor. Dalam penelitian ini diperkirakan bahwa CFO berpengaruh negatif terhadap kualitas audit.

\section{Teknologi Audit KAP (Big-4)}

Blokdijk et al. (2006) menyatakan bahwa kualitas audit adalah fungsi dari tiga faktor produksi, yaitu kualitas input, intensitas input dan 
teknologi yang tersedia untuk mentransformasi input menjadi output. Kualitas input ditunjukkan oleh keahlian, pengetahuan dan pengambilan keputusan dalam menyelenggarakan audit, seperti sumber daya manusia (O'Keefe et al.,1994). Intensitas input adalah jumlah jam kerja auditor dalam melaksanakan proses audit (Hackenbrack dan Knechel, 1997). Sedangkan teknologi auditor adalah audit program, audit software, dan teknologi lain yang membantu proses audit. Pada penelitian ini teknologi audit akan diukur dari afiliasi dengan KAP Asing. KAP yang memiliki afiliasi dengan Big 4 akan memperoleh audit program dan audit software serta peer review dari Big 4 dengan kualitas yang lebih baik dibandingkan dengan KAP lainnya. Sehingga ekspektasi penelitian ini adalah perusahaan yang diaudit oleh KAP yang merupakan affiliasi Big 4 akan memiliki kualitas audit yang lebih baik dibandingkan dengan KAP non affiliasi.

\section{Risiko Pasar (MKT_RISK)}

Untuk mengukur risiko pasar dapat digunakan beta. Namun karena perhitungan ERC dapat menimbulkan multikolinieritas dengan BETA, maka digunakan standar deviasi return saham sebagai pengukur risiko pasar. Semakin besar risiko pasar, semakin besar risiko suatu perusahaan, semakin besar pula risiko auditnya. Ini berarti semakin tinggi risiko audit. Semakin rendah kualitas auditnya. Diprediksi koefisien MKT_RISK memiliki tanda negatif. MKT_RISK diukur dengan standard deviasi dari return saham mingguan (STDEV).

\section{Pengujian Model}

Pengujian dilakukan dengan balanced panel karena balanced panel mengakomodasi informasi baik yang terkait dengan variabel-variabel cross section maupun time series. Data panel secara substansial mampu menurunkan masalah omittedvariables (Gujarati, 2003). Dilakukan HausmanTest untuk mengetahui apakah model tersebut menggunakan random effect atau fixed effect. Untuk data panel, hanya perlu diuji multikolinieritas, autokorelasi dan heteroscedacitas tidak perlu diuji.

Multikolinieritas sering muncul pada model regresi berganda yang menggunakan variabel interaksi. Variabel interaksi adalah perkalian aritmatik dari dua atau lebih variabel bebas, sehingga akan berkolerasi tinggi dengan salah satu atau kedua variabel asalnya. Pada penelitian ini, bila ada masalah multikolinieritas akibat faktor interaksi diatasi dengan teknik centering (Cronbach,
1987), di mana setiap nilai observasi data dari variabel dikurangi dengan nilai rata-rata (mean) dari observasi secara keseluruhan. Centering hanya dilakukan untuk variabel yang memiliki nilai Variance Inflation Factor (VIF) yang tinggi.

Uji multikolinieritas dapat dilihat dari koefisien korelasi atau nilai VIF hasil regresi. Sesuai ketentuan disiplin ilmu statistik, nilai VIF yang baik harus lebih kecil dari 10 (Gujarati, 2003). Pada penelitian ini, untuk variabel yang merupakan hasil interaksi dari dua variabel, ada beberapa yang memiliki nilai VIF di atas 10. Multikolinieritas tetap ada walaupun sudah dilakukan centering. Menurut Gujarati (2003) jika ada masalah multikolinieritas dapat dilakukan dua cara yaitu tidak melakukan apa-apa dan mengikuti beberapa rule of thumb. Blanchard dalam Gujarati (2003) menyatakan bahwa multikolinieritas adalah God's will, bukan merupakan masalah bagi OLS dan teknik statistik lainnya. Terkadang data yang tersedia memang mengandung multikolinieritas. Oleh karena itu, analisis statistik tetap dapat dilanjutkan. Alat statistic yang digunakan adalah eviews.

\section{HASIL PENELITIAN DAN PEMBAHASAN}

\section{Sampel Penelitian}

Penelitian ini menggunakan sampel perusahaan yang terdaftar di Bursa Efek Indonesia (BEI) pada tahun 1999 sampai 2008. Metode pemilihan sampel adalah purposive sampling dengan kriteria perusahaan terdaftar di BEI selama periode observasi, tidak termasuk dalam industri keuangan (bank, sewa guna usaha, asuransi, investasi) karena industri tersebut memiliki struktur laporan keuangan yang berbeda sehingga ukuran kualitas laba yang digunakan tidak dapat disamakan dengan industri lainnya, mempunyai tanggal tutup buku 31 Desember, mempunyai data yang lengkap untuk pengukuran keseluruhan variabel. Prosedur pemilihan sampel dapat dilihat pada Tabel 4. Total sampel adalah 824 perusahaan (103 perusahaan yang sama setiap tahun untuk ke-4 pengukuran kualitas audit).

\section{Statistik Deskriptif}

Tabel 5 menyajikan statistik deskriptif pada periode pra. Pada pra-regulasi, tenure KAP (TENURE) rata-rata 6.2 tahun, nilai maksimum 21 tahun, minimum 1 tahun. Angka rata rata mendekati ketentuan maksimal tenure yang diijinkan oleh KMK yaitu 6 tahun. Pada periode praregulasi hanya sekitar 9\% perusahaan sampel yang melakukan pergantian KAP, kebanyakan 
Tabel 4. Pemilihan Sampel

\begin{tabular}{lccccccccc}
\hline Tahun & 1999 & 2000 & 2001 & 2004 & 2005 & 2006 & 2007 & 2008 & Total \\
\hline TotaL Perusahaan yang listing di BEI & 307 & 307 & 323 & 330 & 339 & 343 & 343 & 343 & 2635 \\
Perusahaan di industry bank, asuransi, leasing & $(51)$ & $(56)$ & $(55)$ & $(63)$ & $(69)$ & $(70)$ & $(76)$ & $(76)$ & $(516)$ \\
Perusahaan Non Keuangan & 256 & 251 & 268 & 267 & 270 & 273 & 267 & 267 & 2119 \\
Data tidak diperoleh untuk semua variable penelitian & $(153)$ & $(148)$ & $(165)$ & $(164)$ & $(167)$ & $(170)$ & $(164)$ & $(164)$ & $(1295)$ \\
\hline Sampel & 103 & 103 & 103 & 103 & 103 & 103 & 103 & 103 & 824 \\
\hline
\end{tabular}

Tabel 5. Statistik Deskriptif

\begin{tabular}{|c|c|c|c|c|c|c|c|c|c|c|}
\hline & \multicolumn{5}{|c|}{ PRAREGULASI } & \multicolumn{5}{|c|}{ PASCAREGULASI } \\
\hline & Minimum & Maximum & Mean & $\begin{array}{c}\text { Std. } \\
\text { Deviation }\end{array}$ & Skewness & Minimum & Maximum & Mean & $\begin{array}{c}\text { Std. } \\
\text { Deviation }\end{array}$ & Skewness \\
\hline $\mathrm{CFO} \mathrm{t}+1$ & -0.51 & 5.55 & 0.20 & 0.63 & 5.65 & -1.63 & 6.78 & 0.09 & 0.36 & 13.28 \\
\hline INC & -1.02 & 1.49 & 0.03 & 0.19 & 0.35 & -0.63 & 0.94 & 0.03 & 0.11 & 0.73 \\
\hline EPS & -20.38 & 21.56 & 0.14 & 3.18 & -0.18 & -15.47 & 26.10 & 0.07 & 1.49 & 7.87 \\
\hline $\mathrm{R}$ & -1.86 & 4.84 & 0.48 & 1.16 & 1.21 & -2.01 & 4.85 & 0.25 & 0.62 & 1.40 \\
\hline ABSDAC & 0.00 & 1.04 & 0.11 & 0.12 & 3.16 & 0.00 & 0.84 & 0.06 & 0.07 & 4.72 \\
\hline CAR & -2.27 & 3.88 & 0.30 & 1.04 & 1.12 & -2.01 & 2.63 & 0.29 & 0.76 & 0.75 \\
\hline UE & -8.64 & 8.27 & 0.15 & 2.31 & 0.38 & -10.93 & 11.00 & -0.04 & 2.85 & -0.11 \\
\hline TENURE & 1.00 & 21.00 & 6.20 & 3.71 & 0.73 & 1.00 & 20.00 & 6.93 & 5.26 & 0.57 \\
\hline ROTATION & 0.00 & 1.00 & 0.09 & 0.29 & 2.80 & 0.00 & 1.00 & 0.15 & 0.36 & 1.95 \\
\hline SPEC & 0.00 & 1.00 & 0.59 & 0.49 & -0.38 & 0.00 & 1.00 & 0.50 & 0.50 & -0.01 \\
\hline BIG4 & 0.00 & 1.00 & 0.86 & 0.35 & -2.10 & 0.00 & 1.00 & 0.57 & 0.49 & -0.30 \\
\hline LEV & 0.03 & 4.60 & 0.74 & 0.57 & 3.17 & 0.03 & 4.37 & 0.60 & 0.38 & 3.92 \\
\hline GROWTH & -6.51 & 9.64 & 1.19 & 1.80 & 1.45 & -10.98 & 21.26 & 1.47 & 2.45 & 3.87 \\
\hline SIZE & 17.35 & 24.79 & 20.35 & 1.37 & 0.35 & 11.52 & 25.24 & 20.52 & 1.92 & -1.19 \\
\hline D LOSS & 0.00 & 1.00 & 0.28 & 0.45 & 1.01 & 0.00 & 1.00 & 0.23 & 0.42 & 1.28 \\
\hline STDEV & 0.00 & 0.37 & 0.10 & 0.05 & 1.68 & 0.00 & 0.55 & 0.08 & 0.05 & 3.10 \\
\hline CFOt & -0.48 & 3.77 & 0.15 & 0.40 & 6.13 & -0.41 & 25.22 & 0.11 & 1.11 & 22.34 \\
\hline $\begin{array}{l}\text { TA (DLM } \\
\text { JUT AAN) }\end{array}$ & 34.31 & 58275.21 & 2067.10 & 5113.19 & 6.68 & 0.10 & 610000.00 & 6783.90 & 39713.60 & 13.11 \\
\hline $\begin{array}{l}\text { Valid N } \\
\text { (listwise) }\end{array}$ & & & 309.00 & & & & & 515.00 & & \\
\hline
\end{tabular}

Ket: CFO t+1: Arus Kas Operasi (diskalakan terhadap total asset) untuk perusahaan i pada tahun t+1; INC: Laba sebelum pos luar biasa dan operasi yang dihentikan (diskalakan terhadap total asset) untuk perusahaan i pada tahun t; EPS: Laba per lembar saham; R: return saham; ABSDAC: Nilai absolut akrual diskresioner perusahaan i pada waktu t; CAR: Cummulative Abnormal Return selama periode 12 bulan yang berakhir pada 3 bulan setelah tahun fiscal; UE: Unexpected Earnings, merupakan selisih laba akuntansi yang direalisasi dengan laba akuntansi yang diekspektasi oleh pasar; TENURE: Jangka waktu penugasan KAP pada suatu perusahaan pada tahun tertentu (jumlah tahun).; ROTATION: 1 jika terjadi rotasi KAP riil, 0 tidak terjadi rotasi KAP rill; SPEC: $d u m m y$ variabel, 1 : jika perusahaan tergolong spesialis, 0 lainnya; BIG4: KAP yang mengaudit Perusahaan, 1:BIG-4, 0 lainnya; LEV: Total utang dibagi dengan total asset; GROWTH: Persentase pertumbuhan penjualan dari tahun sebelumnya; SIZE: Ukuran Perusahaan diukur dengan Total Aset; DLOSS: Dummy variabel, 1 apabila perusahaan mengalami kerugian, dan 0 lainnya; STDEV: Dummy variabel, 1 apabila perusahaan mengalami kerugian, dan 0 lainnya; CFO Arus Kas Operasi (diskalakan terhadap total asset) untuk perusahaan i pada tahun t.

perusahaan hanya mengalami pergantian Audit Partner (32\%). Perusahaan sampel yang diaudit oleh auditor spesialisasi dan yang bukan spesialis, jumlahnya berimbang yaitu $59 \%$ dan $41 \%$ dan sebagian besar perusahaan sampel (86\%) diaudit oleh KAP yang termasuk dalam Big-4 (Big-5).

Pada periore pascaregulasi, tenure KAP rill rata-rata adalah 6.93 tahun, minimum 1 tahun, dan maksimum 20 tahun. Persentase perusahaan sampel yang melakukan rotasi partner dan KAP mengalami peningkatan dibandingkan periode sebelum regulasi $(50 \%$ dan $15 \%$ setelah regulasi dibandingkan $32 \%$ dan $9 \%$ sebelum regulasi). Perusahaan sampel yang diaudit oleh auditor spesialisasi dan yang bukan spesialis berimbang yaitu $50 \%$ dan $50 \%$. Perusahaan sampel yang diaudit oleh KAP Big-4 (Big-5)mengalami penurunan yang signifikan dibandingkan sebelum regulasi $(57 \%$ sesudah penerapan dan $86 \%$ sebelum penerapan). 


\section{Hasil Regresi}

\section{Pengaruh Tenure KAP terhadap Kualitas Audit}

\section{Netralitas}

Tabel 6 menunjukkan hasil regresi untuk kualitas audit yang dilihat dari sisi netralitas (DAC). Pada periode praregulasi tidak ditemukan hubungan kuadratik antara tenure KAP dan kualitas audit. Hubungan yang ditemukan adalah linier positif antara TENURE dengan akrual diskresioner (DAC) atau dengan kata lain berhubungan negatif dengan kualitas audit yang dilihat dari sisi netralitas (lihat tabel 6). Semakin panjang tenure, semakin besar akrual diskresioner atau semakin rendah kualitas audit. Hal ini kemungkinan disebabkan karena dengan semakin panjangnya tenure, hubungan auditor dengan klien semakin dekat, sehingga independensi auditor menurun. Hasil ini konsisten dengan temuan Knechel dan Vanstraelen (2007) yang menemukan hubungan negatif antara tenure dan kualitas audit.

Tabel 6. Hasil Regresi Model 1 (Netralitas)

\begin{tabular}{|c|c|r|r|r|r|r|r|r|r|}
\hline & \multicolumn{6}{|c|}{ PRAREGULASI } & \multicolumn{5}{|c|}{ PASCAREGULASI } \\
\hline Variable & & Coefficient & Prob. & & VIF & Coefficient & Prob. & & VIF \\
\hline C & & $-0,142$ & 0,020 & & & 0,085 & 0.000 & & \\
\hline TENURE & $+/-$ & 0,016 & 0.000 & $* * *$ & 2,8 & 0,270 & 0.000 & $* * *$ & 13,4 \\
\hline TENURESQ & $+/-$ & 0,000 & 0,136 & & 2 & $-0,013$ & 0.000 & $* * *$ & 13,3 \\
\hline ROTATION & $+/-$ & 0,082 & 0.000 & $* * *$ & 1,7 & $-0,004$ & 0,150 & & 1,1 \\
\hline SPEC & - & 0,029 & 0.000 & $* * *$ & 1,2 & $-0,000$ & 0,436 & & 1,7 \\
\hline BIG4 & - & $-0,048$ & 0,002 & $* * *$ & 1,4 & $-0,001$ & 0,349 & & 1,6 \\
\hline LEV & $+/-$ & 0,006 & 0,091 & $*$ & 1,2 & 0,010 & 0,149 & & 1,2 \\
\hline GROWTH & - & 0,004 & 0,012 & $* *$ & 1 & 0,001 & 0,021 & $* *$ & 1,1 \\
\hline SIZE & $+/-$ & 0,012 & 0.000 & $* * *$ & 1,1 & $-0,001$ & 0,011 & $* *$ & 1,1 \\
\hline D_LOSS & - & $-0,015$ & 0.000 & $* * *$ & 1,1 & $-0,002$ & 0,219 & & 1,2 \\
\hline CFO & - & 0,021 & 0.000 & $* * *$ & 1,1 & $-0,002$ & 0.000 & $* * *$ & 1 \\
\hline N & & 309 & & & & 515 & & \\
\hline Adjusted R-squared & & 0,756 & & & 0,863 & & \\
\hline Durbin-Watson stat & & 3.053 & & & & 1.542 & & \\
\hline Prob(F-statistic) & & 0.000 & & & 0.000 & & \\
\hline
\end{tabular}

DepVar: DAC

DAC $=\mathrm{c}+\mathrm{bTENURE}+\mathrm{aTENURESQ}$

Minimum point : $-\mathrm{b} / 2 \mathrm{a}=-0.270 /(2 \mathrm{x}-0.013)=10.1$ years

Pada periope pascaregulasi, Tabel 6 menunjukkan bahwa variabel TENURE bernilai signifikan positif dan TENURESQ signifikan negatif. $\mathrm{Hal}$ ini menunjukkan bahwa TENURE verhubungan concave dengan akrual diskresioner (lihat gambar 4).

Karena tenure berhubungan concave dengan akrual diskresioner, dimana akrual diskresioner berbanding terbalik dengan kulitas audit, maka dapat disimpulkan bahwa tenure berhubungan convex dengan kualitas audit (lihat gambar 5).

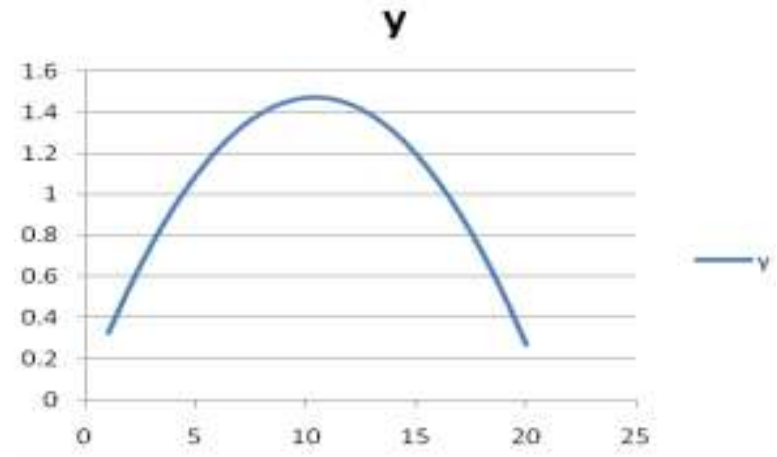

Gambar 4. Hubungan Tenure KAP dan akarual diskresioner pascaregulasi (dari sisi netralitas)

Kualitas Audit

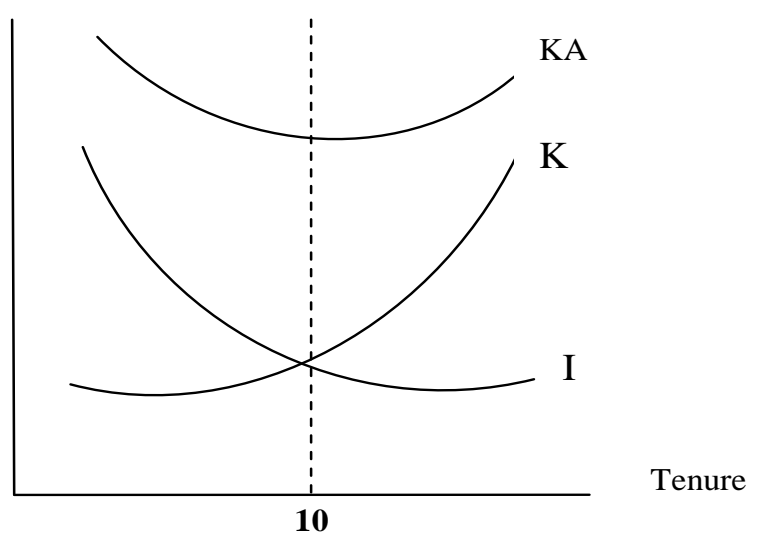

Gambar 5. Hubungan tenure KAP dan kualitas audit pada periode pascaregulasi (dari sisi netralitas)

Titik minimum dari kurva tersebut, yaitu pada saat tenure KAP 10 tahun (perhitungan lihat pada tabel 6). Hal ini menunjukkan bahwa kualitas audit akan turun terus sampai masa penugasan KAP mencapai 10 tahun. Setelah 10 tahun, baru kualitas audit akan naik. Dengan relatif lamanya waktu yang diperlukan sebelum kualitas audit naik (membutuhkan waktu 10 tahun), sebenarnya pola hubungan antara tenure KAP dan kualitas audit dari sisi netralitas tidak berbeda antara periode pra dan pascaregulasi, sama-sama berhubungan negatif.

\section{Representational Faithfulness}

Tabel 7 menyajikan hasil pengujian dengan kualitas laba dari sisi Representational Faithfullness sebagai ukuran kualitas audit. Hasil pengujian menunjukkan bahwa pada periode pra dan pasca regulasi variable TENURE dan TENURESQ tidak signifikan yang artinya tidak ada hubungan antara panjangnya tenure dengan kualitas audit dari sisi Representational Faithfullness. 
Tabel 7. Hasil Regresi Model 2 (Representational Faithfullness)

\begin{tabular}{|c|c|c|c|c|c|c|c|c|c|}
\hline & & \multicolumn{4}{|c|}{ Praregulasi } & \multicolumn{4}{|c|}{ Pascaregulasi } \\
\hline Variable & & Coefficient & Prob. & & VIF & Coefficient & Prob. & & \\
\hline $\mathrm{C}$ & & 1.173 & 0,074 & & & 0,064 & 0,069 & & \\
\hline UE & $+1-$ & $-0,144$ & 0,276 & & 19,2 & $-0,031$ & 0,344 & & 3. \\
\hline UETENURE & $+1-$ & 0,032 & 0,206 & & 72,3 & 0,012 & 0,187 & & 3.6 \\
\hline UETENURESQ & $+1-$ & 0,001 & 0,242 & & 27 & 0,000 & 0,170 & & 4.9 \\
\hline UEROTATION & $+/-$ & 0,093 & 0,400 & & 1,6 & 0,027 & 0,483 & & 2.8 \\
\hline UESPEC & + & $-0,014$ & 0,343 & & 2,8 & 0,008 & 0,209 & & 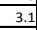 \\
\hline BIG4 & + & 0,024 & 0,499 & & 1 & $-0,017$ & 0,437 & & 1.1 \\
\hline LEV & $+/-$ & 0,430 & 0,010 & $* * *$ & 1,6 & 0,103 & 0,578 & & \\
\hline GROWTH & + & 0,153 & 0,000 & $* * *$ & 1,1 & 0,06 & 0,003 & $* * *$ & 1.1 \\
\hline SIZE & $+/-$ & $-0,063$ & 0,134 & & -1 & $-0,039$ & 0,035 & *** & 1.1 \\
\hline D_LOSS & + & $-0,274$ & 0,033 & $* *$ & 1,3 & 0,02 & 0,398 & & 1.3 \\
\hline STDEV & + & $-0,012$ & 0,000 & $* * *$ & 1, & 4,836 & 0,000 & $* * *$ & - \\
\hline $\mathrm{N}$ & & 309 & & & & 515 & & & \\
\hline Adjusted R-squared & & 0,04 & & & & 0,07 & & & \\
\hline rbin-V & & 2,37 & & & & 1,93 & & & \\
\hline & & & & & & & & & \\
\hline
\end{tabular}

DepVar: CAR

\section{Predictability}

Tabel 8 menyajikan hasil pengujian dengan kualitas laba dari sisi predictability sebagai ukuran kualitas audit. Hasil pengujian juga menunjukkan bahwa variable TENURE dan TENURESQ tidak signifikan pada periode pra dan pasca regulasi, yang artinya tidak ada hubungan signifikan antara panjangnya tenure dengan kualitas audit dari sisi prediktability.

Tabel 8. Hasil Regresi Model 3 (Prediktabilitas)

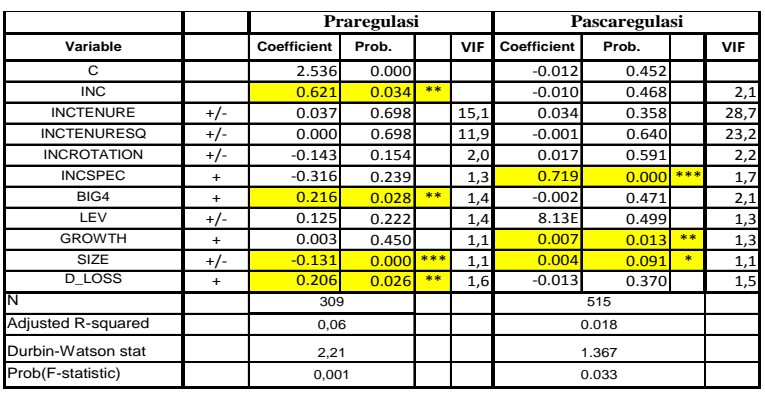

Dep.Var: CFO

\section{Timeliness}

Tabel 9 menunjukkan bahwa pada periode pascaregulasi, variabel RTENURE signifikan negatif dan variabel TENURESQ signifikan positif. Hasil ini menunjukkan adanya hubungan kuadratik conveks antara tenure KAP dan kualitas audit dari sisi timeliness.

Tabel 9. Hasil Regresi Model 4 (Timeliness)

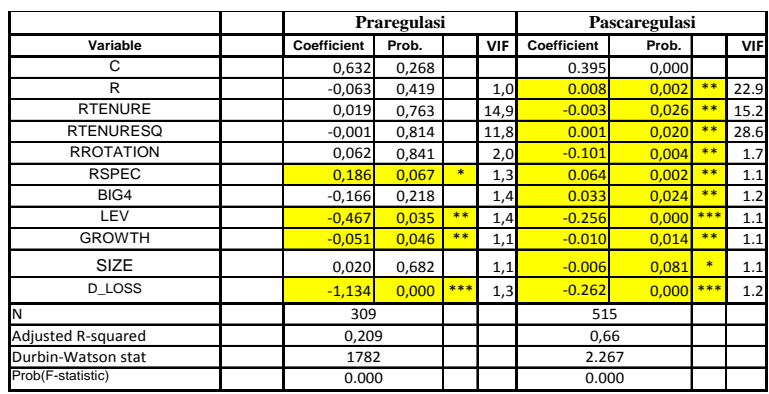

DepVar: EPS

EPS $=\mathrm{c}+\mathrm{bRTENURE}+\mathrm{aRTENURESQ}$

Minimum point: $-\mathrm{b} / 2 \mathrm{a}=-(-0.003) /(2 \times 0.001)=1.5$ years
Perhitungan diatas menunjukkan bahwa titik minimum adalah 1,5. Hasil ini menunjukkan bahwa pada 1.5 tahun awal penugasan, kualitas audit dari sisi timeliness turun dahulu, setelah itu kualitas audit akan naik.

Temuan ini konsisten dengan temuan St. Pierre dan Anderson (1984) bahwa pada tiga tahun awal periode penugasan, kualitas audit masih rendah. Rendahnya kualitas audit karena auditor belum memahami kliennya secara mendalam (Francis dan Simon 1987; Balvers et al. 1988; Beatty 1989; Craswell et al. 1995).

Kualitas Audit

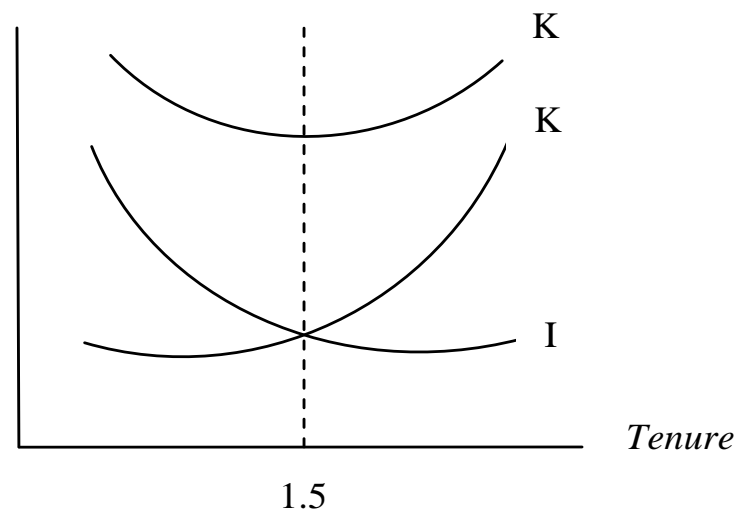

Gambar 6. Hubungan tenure KAP dan kualitas audit pada periode pascaregulasi (dari sisi timeliness)

\section{Pengaruh Rotasi KAP terhadap Kualitas Audit}

Hipotesis 2 yang menyatakan bahwa rotasi KAP berpengaruh terhadap kualitas audit tidak terbukti pada penelitian ini, kecuali untuk kualitas audit yang dilihat dari sisi netralitas pada periode praregulasi (lihat variable ROTASI pada table 6) dan pada periode padcaregulasi untuk kualitas audit yang dilihat dari sisi timeliness. Tidak terbuktinya pengaruh rotasi KAP terhadap kualitas audit menunjukkan bahwa dengan adanya rotasi KAP, kualitas audit tidak berubah. Hal ini mungkin disebabkan karena dengan adanya rotasi $\mathrm{KAP}$, disatu sisi independensi KAP meningkat (karena KAP dan klien belum terlalu familiar), namun di sisi lain kompetensi KAP masih rendah (karena KAP belum cukup memiliki pengetahuan mengenai risiko dan karakteristik bisnis klien). Peningkatan independensi sama besarnya dengan penurunan kompetensi, sehingga secara total, kualitas audit tidak berubah.

Terbuktinya pengaruh rotasi terhadap kualitas audit yang dilihat dari sisi netralitas pada periode praregulasi menunjukkan bahwa pada periode praregulasi, jika terjadi rotasi KAP, maka akrual diskresioner akan meningkat, yang artinya 
kualitas audit turun. Hal ini mungkin disebabkan karena KAP yang baru belum cukup memiliki pengetahuan mengenai risiko dan karakteristik bisnis perusahaan sehingga terlalu tergantung pada asersi manajemen sehingga meningkatkan manajemen laba (Gul at al. 2007). Pada periode pascaregulasi untuk kualitas audit yang dilihat dari sisi timeliness juga ditemukan hasil yang sama bahwa ROTASI berpengaruh negative terhadap kualitas audit.

\section{Pengaruh Spesialisasi Audit terhadap Kualitas Audit}

Pada tabel 6 dapat dilihat bahwa pada periode praregulasi, variabel spesialisasi berpengaruh positif terhadap akrual diskresioner. Hasil ini menunjukkan bahwa semakin spesialis seorang auditor, maka semakin besar akrual diskresioner pada perusahaan yang diauditnya. Hubungan positif spesialisasi dengan akrual diskresioner berarti ada hubungan negatif antara spesialisasi dengan kualitas audit. Temuan ini bertentangan dengan prediksi awal dimana spesialisasi diprediksikan berhubunagn positif dengan kualitas audit. Hal ini mungkin disebabkan karena kurangnya independensi auditor spesialis. Selain mencerminkan tingginya kompetensi, spesialisasi juga mencerminkan independesi. Temuan ini sesuai dengan hasil penelitian Kallapur et al. (2008) mengenai efek audit market concentration terhadap kualitas audit di mana semakin tinggi market concentration, semakin rendah kualitas audit. Pada umumnya, KAP spesialis menguasai pangsa pasar pada suatu industri. Untuk mempertahankan market power di suatu industri tertentu, maka ada kemungkinan KAP spesialis terpaksa mengorbankan independensinya demi mempertahankan kliennya. Penurunan kualitas audit yang disebabkan karena penurunan independensi ini lebih besar dibandingkan kenaikan kualitas audit karena spesialisasinya. Jadi, walaupun auditornya spesialis, karena independensi mereka terganggu, kualitas audit justru turun.

Setelah adanya regulasi, spesialisasi partner berpengaruh positif terhadap kualitas audit dari sisi prediktabilitas (Tabel 8). Dengan adanya aturan rotasi, terjadi perubahan tingkat konsentrasi pasar audit pada periode pascaregulasi. Berdasarkan penelitian Zef dan Siregar (2010), terjadi perubahan struktur pasar audit di Indonesia dari monopoli (2000-2001) menjadi oligopoli kuat sampai tahun 2005 (tahun penelitian hanya sampai 2005). Perubahan struktur pasar ini menyebabkan perubahan market concentration. Menurut Kallpur et al. (2008) semakin rendah market concentration, semakin tinggi kualitas audit. Dengan adanya regulasi, market concentration akan berkurang. Maka, auditor harus meningkatkan kualitas audit (spesialisasi) agar dapat bersaing di pasar audit (memperoleh klien baru).

Variabel spesialisasi tidak memengaruhi tingkat representational faithullness (respons investor terhadap laba suatu perusahaan), baik sebelum maupun setelah regulasi diberlakukan. Hal ini mungkin disebabkan informasi mengenai spesialisasi industri auditor tidak dapat diketahui secara eksplisit oleh pasar seperti penjelasan berikut. Penentuan tingkat spesialisasi berbedabeda. Palmrose (1986) dan Dunn, dan Mayhew (2000) mengidentifikasi auditor spesialis berdasarkan dominasi KAP pada pangsa pasar dan penjualan klien di suatu industri. Hogan dan Jeter (1999) dan Mayhew dan Wilkins (2002) menentukan auditor spesialis berdasarkan dominasi total aset perusahaan klien di suatu industri. Balsam et al. (2003) menentukan auditor spesialis berdasarkan dominasi dalam jumlah klien dalam suatu industri. Perbedaan penentuan auditor spesialis ini juga diduga membuat pasar menginterpretasikan spesialis dengan cara yang berbeda-beda sehingga tidak tertangkap hubungan antara spesialisasi industri auditor dengan koefisien respons pasar.

Untuk kualitas audit dari sisi timeliness, variable SPESIALISASI ditemukan berpengaruh positif terhadap kualitas audit baik sebelum maupun setelah regulasi (tabel 9). Hasil ini menunjukkan bahwa semakin spesialis auditor yang mengaudit suatu perusahaan, semakin baik kualitas audit dimana current return lebih mampu merefleksikan future earnings.

\section{KESIMPULAN DAN SARAN}

Pada periode praregulasi, hubungan tenure KAP dengan kualitas audit dari netralitas berbentuk linier negatif, yang artinya semakin panjang tenure KAP, semakin rendah kualitas audit. Untuk kualitas audit dari sisi lainnya, tenure KAP tidak ditemukan berpengaruh secara signifikan terhadap kualitas audit.

Pada periode pascaregulasi, ditemukan hubungan kuadratik convex antara tenure KAP dan kualitas audit dari sisi netralitas dan timeliness. Dari sisi netralitas, pada awal penugasan audit, kualitas audit akan turun dahulu sampai 10 tahun, baru kemudian naik. Sedangkan dari sisi timeliness, penurunan kualitas audit terjadi sampai tahun ke-1.5, setelah itu kualitas audit naik. Dari sisi representational faithfullness dan predictability, tenure KAP tidak signifikan memengaruhi kualitas audit. 
Untuk variabel rotasi, pada periode praregulasi, rotasi KAP ditemukan berpengaruh negatif terhadap kualitas audit dari sisi netralitas, belum ditemukan pengaruh terhadap pengukuran kualitas audit yang lain. Pada periode pascaregulasi ditemukan pengaruh positif rotasi KAP terhadap kualitas audit dari sisi timeliness. Sehingga dapat disimpulkan secara umum bahwa rotasi KAP belum berpengaruh terhadap kualitas audit. Temuan ini membuktikan bahwa aturan rotasi belum dapat meningkatkan kualitas audit, sehingga pemerintah perlu memikirkan langkahlangkah untuk meningkatkan kualitas audit. Regulasi mengenai rotasi KAP perlu dipertimbangkan kembali.

Pada periode praregulasi, spesialisasi KAP berpengaruh negatif terhadap kualitas audit dari sisi netralitas, namun berpengaruh positif dari sisi timeliness. Kondisi pada praregulasi bertentangan dengan prediksi awal, kemungkinan walaupun auditor spesialis, namun memiliki independensi yang rendah sehingga kualitas audit juga rendah. Hal ini mungkin disebabkan karena adanya usaha auditor spesialis untuk mempertahankan market power di suatu industri tertentu yang mengakibatkan penurunan independensi.

Pada periode pascaregulasi, spesialisasi KAP meningkatkan kualitas audit dari sisi prediktabilitas dan timeliness. Hal ini kemungkinan karena adanya regulasi rotasi dan aturan pembatasan jasa non-audit serta semakin meningkatnya standar audit sehingga menyebabkan peningkatan independensi dan kompetensi auditor spesialis.

Keterbatasan penelitian ini antara lain: penelitian ini menggunakan sampel hanya perusahaan yang terdaftar di Bursa Efek Indonesia, maka generalisasi hasil penelitian pada perusahaan tertutup harus dilakukan secara hati-hati. Kualitas audit sangat sulit diukur, penelitian ini menggunakan kualitas laba sebagai proksi dari kualitas audit yang banyak digunakan peneliti sebagai proksi kualitas audit. Penelitian selanjutnya dapat menggunakan proksi kualitas audit yang lain yang lebih merepresentasikan kualitas audit, misalnya memasukkan unsur kepatuhan pada Standar Profesional Akuntan Publik (SPAP). Penelitian ini belum memasukkan aspek Corporate Governance (CG) di dalam model seperti efektifitas komite audit, struktur kepemilikan saham perusahaan, efektifitas komisaris, indeks CG, dan lain lain. Dapat juga dilakukan pengujian dengan mempertimbangkan perbedaan karakteristik antar-industri.

\section{DAFTAR PUSTAKA}

Balsam, S., Khrisnan, J., and Yang, Y.S. (2003). Auditor Industry Specialization and Earnings
Quality. Auditing: A Journal of Practice \& Theory, 22, 71-97.

Beatty, R. P. (1989). Auditor Reputation and The Pricing of Initial Public Offering. The Accounting Review 64(Oct), 693-709.

Beaver, W. H. (1989). Financial Reporting: An Accounting Revolution. Englewood Cliffs, N.J.: Prentice Hall.

Becker, C. L., Defond, M. L., Jiambalvo, J., and Subramanyam, K. R. (1998). The Effect of Audit Quality on Earnings Management. Contemporary Accounting Research 15.

Boone, J. P., Khurana, I. K., and Raman, K. K (2008). Audit Firm Tenure and The Equity Risk Premium. Journal of Accounting, Auditing \& Finance, 23(1), 115-140.

Carcello, J. V. and Nagy, A. L. (2004). Audit firm Tenure and Fraudulent Financial Reporting. Auditing: A Journal of Practice and Theory 23(2), 55-69.

Cameran, M., Di Vincenzo, D., and Merlotti, E. (2005). Audit firm rotation: A review of the literature. SDA Bocconi Research Paper. Retreived from http://www.ssrn.com/abstract= 825404.

Comunale, C. L. and Sexton, T. R. (2005). Mandatory Auditor Rotation and Retention: Impact on market share. Managerial Auditing Journal, 20(3), 235-248.

Chi, W., (2005). Mandatory Audit-Partner Rotation, Audit Quality and Market Perception: Evidence from Taiwan www.ssrn.com.

Craswell, A. T., Francis, J. R., and Taylor, S. L. (1995). Auditor Brand Name Reputations and Industry Specialization, Journal of Accounting and Economics (20), 297-322.

Davis, L., Soo, B., and Trompeter, G. (2009). Auditor Tenure and The Ability To Meet or Beet Earnings Forecsts, Contemporary Accounting Research, 26(2).

Davis, R., Soo, B., and Trompeter, G. (2002). Auditor tenure, auditor independence and earnings management. Working Paper, Boston College, Boston, MA.

DeAngelo, L. E. (1981). Auditor Size and Audit Quality. Journal of Accounting and Economics, 3(1), 167-175.

Dimitripoulos, P., Asteriou, E., and Dimitrios (2008). Timeliness, Conservatism and Financial Transparent Firms Under the Greek Accounting Setting. UK Review of Accounting and Finance, 7(3), 252-269.

Ding, Y., Stowoly, and Herve (2006). Timeliness and Conservatism Changes Over Time in The Properties of Accounting Income in France. Department of Accounting and Management Control, HEC School of Management (Groupe HEC), Jouy-en-Jisas, Yvelines, France. 
Dopuch, N., King, R. R., and Schwartz, R. (2001). An Experimental Investigation of Retention and Rotation Requirements, Journal of Accounting Research, 39(1), 93-117.

Earnest and Young, (2013). Q\&A on Mandatory Firm Rotation http://www.ey.com/Publication/ vwLUAsset,s/EY-qa-on-mandatory-firm-rotation-march-2013/\$FILE/EY-qa-on-mandatoryfirm-rotation-march-2013.pdf. Diunduh pada tanggal 1 April 2015

Fitriany dan Arie, W. (2009). Perlukah Regulasi KAP di Indonesia, Laporan Project Grant Departemen Akuntansi FEUI.

Fitriany dan Rosietta, H. (2009). Analisis Aturan Rotasi KAP di Indonesia: Peran Corporate Governance dalam Memoderasi Hubungan antara Jangka Waktu Penugasan Audit \& Kualitas Audit, Makalah Simposium Ekonomi Nasional ke IV, Surabaya.

Gavious, I. (2007). Alternative Perspectives to Deal with Auditors' Agency Problem, Critical Perspectives on Accounting, 18, 451-467

Geiger, M. A., dan K. Raghunandan (2002). Auditor Tenure and Audit Reporting Failure. Auditing: A Journal of Practice and Theory 21(1), 67-78.

Gelb, D. and Zarowin, P. (2000). Corporate Disclosure Policy and the Informativeness of Stock Prices. Style sheet. http//papers.ssrn. com

Gujarati, D. N. (2003). Basic Econometrics $4^{\text {th }}$ Edition. New York: McGraw Hill

Gul, F. A., Fung, S. Y. K., and Jaggi, B. (2009). Earnings Quality: Some Evidence on the Role of Auditor Tenure and Auditors' Industry Expertise. Journal of Accounting and Economics, 47, 265-287.

Healy, P. and Lys, T. (1986). Auditor Changes Following Big-4 Eight Takeovers of Non Big-4 Eight Firms. Journal of Accounting and Public Policy (Winter), 251-265.

Jensen, M. and Meckling, W. (1976). Theory of the Firm: Manajerial Behaviour, Agency Costs, and Ownership Structure. Journal of Financial Economics 3(4), 305-360.

Jenkins, D. S., Kane, G. D., Velury, and Uma. (2006). Earnings Quality Decline and the Effect of Industry Specialist Auditors: an Analysis of The Late 1990s, Journal of Accounting and public policy, 25, 71-90.
Kaplan, R. L. (2004). The Mother of All Conflicts: Auditors and Their Clients, Illinois Public Law and Legal Theory Research Series, No. 04-13.

Kasznik, R. (1999). On the Association between Disclosure and Earnings Management. Journal of Accounting Research, 22, 353-367.

Knechel. R. W., Naiker, V., and Pacheco, G. (2007). Auditing: A Journal of Practice and Theory, 26, 19-45.

Krishnan, G. V. (2003). Does Big-4 6 Auditor Industri Expertise Constrain Earnings Management? Accounting Horizon (Suppl.), 1-16.

Lowensohn. (2007). Auditor Specialization, Perceived Audit Quality, and Audit fees in The Local Government Audit Market. Journal of Accounting and Public Policy, 26.

Mautz, R. K. dan Sharaf, H. A. (1961). The Philosophy of Auditing. Sarasota, FL: American Accounting Association.

Palmrose, Z. (1984). The Demand for Quality Differentiated Audit Services in an Agency Cost Setting: An Empirical Investigation. Auditing Research Symposium, 229-252.

Reynolds, J. K. and Francis, J. (2001). Does size matter? The Influence of Large Clients on Office-Level Auditor Reporting Decisions. Journal of Accounting and Economics, 30,375400

Siregar, S., Fitriany, V. N. P., Wibowo, dan Anggraita A. (2009). Laporan Hibah Fakultas Ekonomi UI.

Solomon, I. M., Shields, M., and Whittington, O.R. (1999). What do Industry Auditors Know? Journal of Accounting Research, 37(1), 191208.

St. Pierre, K. and Anderson. J. (1984). An Analysis of Factors Associated with Lawsuits Against Public Accountants. The Accounting Review 59(1), 242-263.

Velury, U. and Jenkins, D. S. (2006). Institutional Ownership and the Quality of Earnings. Journal of Business Research 59, 1043-1051.

Watts, R. dan Zimmerman, J. (1986). Positive Accounting Theory. New York, NY: Prentice Hall.

Wibowo, A, dan Rossieta, H. (2009). Faktor-faktor Determenasi Kualitas Audit-Suatu Studi Dengan Pendekatan Earning Surprise Benchmark. Pascasarjana Ilmu Akuntasi FEUI. 